\title{
INVESTIGATION OF BOTTOM MASS-BALANGE RATES BY ELECTRICAL RESISTIVITY SOUNDINGS ON THE ROSS ICE SHELF, ANTARGTICA*
}

\author{
By Sion Shabtaie and Charles R. Bentley \\ (Geophysical and Polar Research Center, Department of Geology and Geophysics, University \\ of Wisconsin-Madison, Madison, Wisconsin 53706, U.S.A.)
}

\begin{abstract}
Electrical resistivity sounding, using the four-electrode Schlumberger array, has been carried out at i locations on the Ross Ice Shelf. The apparent resistivity curves generally show four characteristic zones. The first, at distances from $\mathrm{I}$ to $\mathrm{ro} \mathrm{m}$, reflects the near-surface zone of seasonal temperature changes and inhomogeneities. The second zone, from $10 \mathrm{~m}$ to $100 \mathrm{~m}$, reflects primarily the increasing density with depth in the upper $50 \mathrm{~m}$ of the ice shelf, modified, in some locations, by temperature variations. The third zone, from $100 \mathrm{~m}$ to a distance roughly equal to the ice thickness, is affected principally by the temperature gradient in the solid ice. In the fourth zone, at distances greater than approximately twice the ice thickness, the apparent resistivity usually decreases rapidly with distance, owing to the highly conductive sea-water beneath the ice shelf. At some stations associated with ice streams and outlet glaciers, however, an increase at large spacings indicates much more resistive basal ice.

Using data from seven locations on the grid eastern half of the shelf that do not show obvious evidence of a basal resistive zone, including temperatures to $100 \mathrm{~m}$ at two of the sites, the mass-balance rate at the bottom of the ice is estimated to be within a few tenths of a meter per year of zero at distances between 90 and $530 \mathrm{~km}$ from the ice front, assuming steady-state condition over most of the ice shelf. However, the assumption of steady-state is questionable at locations close to outlet glaciers, and must be treated with great caution. The temperature measurements at the two sites, along with previously observed temperatures at the RISP drill site, make it possible to estimate the activation energy in the solid ice. The models fitted to the observed values suggest an "apparent" activation energy in the solid ice closer to $0.15 \mathrm{eV}$ ( $14 \mathrm{~kJ} \mathrm{~mol}^{-1}$ ) than to $0.25 \mathrm{eV}\left(24 \mathrm{~kJ} \mathrm{~mol}^{-1}\right)$. This difference is believed to be due to a decrease in the ionic impurity content with increasing depth in the ice by a factor of two or more.
\end{abstract}

RÉsumé. Investigation du bilan de masse au fond par sondages de résistivitéélectrique sur le Ross Ice Shelf en Antarctique. Des sondages de résistivité électrique ont été effectués en i I endroits du Ross Ice Shelf à l'aide d'un capteur Schlumberger à quatre électrodes. Les courbes de résistivité apparente présentent généralement quatre zones caractéristiques. La première à une distance de 1 à $10 \mathrm{~m}$ correspond à la zone superficielle de variation saisonnière de température et d'inhomogénéité. La seconde zone, de 10 à $100 \mathrm{~m}$, correspond d'abord à la densité croissante avec la profondeur dans les $50 \mathrm{~m}$ supérieurs de la couverture de glace, modifiée, en quelques points, par des variations de température. La troisième zone, de $100 \mathrm{~m}$ à une distance sensiblement équivalente à l'épaisseur de la glace est surtout affectée par le gradient de température dans la glace solide. Dans la quatrième zone, à des distances supérieures à environ le double de l'épaisseur de la glace, la résistivité apparente décroît d'ordinaire rapidement avec la distance, en raison de la haute conductivité de l'eau de mer sous la glace. Dans quelques stations où existent des courants de glace et des langues glaciaires, cependant, un accroissement de résistivité à de grandes distances traduit la résistivité beaucoup plus fort de la glace basale.

En utilisant les données de sept points de forage sur la moitié Est du réseau sur la couverture de glace qui ne semble pas posséder de zone basale à forte résistivité, y compris les températures jusqu'à $100 \mathrm{~m}$, en deux de ces points on a estimé le bilan de masse de la glace de fond à quelques dixièmes de mètres par an à des distances de zéro à 90 et $530 \mathrm{~km}$ du front de glace, dans l'hypothèse de conditions d'équilibre sur la plus grande partie de la calotte. Cependant, l'hypothèse d'un état d'équilibre pose des questions à proximité des embouchures des glaciers et doit être traitée avec de grandes précautions. Les mesures de température sur les deux sites, associées avec les observations passées de la température au forage RISP rendent possible l'estimation de l'énergie d'activation dans la glace solide. Les modèles ajustés sur les valeurs observées conduisent à une énergie "apparente" d'activation dans la glace solide plus proche de o, $15 \mathrm{eV}$ ( $14 \mathrm{~kJ} \mathrm{~mol}^{-1}$ ) que de $0,25 \mathrm{eV}\left(24 \mathrm{~kJ} \mathrm{~mol}^{-1}\right)$. Cette différence est due, croit-on, à une diminution de la teneur en impuretés ioniques quand augmente la profondeur dans la glace par un facteur deux ou plus.

Zusammenfassung. Untersuchung der Massenbilanzraten an der Unterseite des Ross Ice Shelf, Antarktika, durch Messung des elektrischen Widerstandes. An i I Stellen des Ross Ice Shelf wurden elektrische Widerstandsmessungen mit der 4-Elektroden-Auslage nach Schlumberger vorgenommen. Die Kurven des scheinbaren Widerstandes zeigen im allgemeinen vier charakteristische Zonen an. Die erste zwischen $1 \mathrm{~m}$ und $10 \mathrm{~m}$ spiegelt die oberflächennahe Zone mit jahreszeitlichen Temperaturschwankungen und Inhomogenitäten wider. Die zweite Zone zwischen $10 \mathrm{~m}$ und $100 \mathrm{~m}$ ist vor allem durch die Zunahme der Dichte mit der Tiefe in den oberen $50 \mathrm{~m}$ des Schelfeises gekennzeichnet, an einzelnen Stellen allerdings durch Temperaturschwankungen modifiziert. Die dritte Zone von $100 \mathrm{~m}$ bis etwa zur vollen Eisdicke ist im wesentlichen durch den Temperaturgradienten im festen Eis beeinflusst. In der vierten Zone, bei Entfernungen von mehr als

* University of Wisconsin. Geophysical and Polar Research Center, Contribution No. 359. 
etwa der zweifachen Eisdicke nimmt der scheinbare Widerstand gewöhnlich schenll mit der Entfernung ab, eine Folge der, stark leitfähigen Meerwassers unter dem Schelfeis. An einigen Stationen, die mit Eisströmen und Ausflussgletschen in Verbindung stehen, deutet jedoch die Zunahme bei grossen Auslagen auf eine untere Eissicht mit weit höheren Widerstand hin.

Mit Hilfe von Daten an sieben Stellen auf der östlichen Hälfte des Schelfeises, die keine deutlichen Anzeichen erhöhten Widerstandes in der Tiefe zeigen, einschliesslich Temperaturen bis roo $\mathrm{m}$ Tiefe an zwei der Stellen, wird die Massenbilanzrate an der Unterseite des Eises auf einige Dezimeter pro Jahr für Distanzen zwischen 90 und $530 \mathrm{~km}$ von der Eisfront abgeschätzt; dabei wird für den Grossteil des Schelfeises ein stationärer Zustand angenommen. Diese Annahme erscheint jedoch zumindest an Stellen nahe den Ausflussgletschern fragwürdig und muss mit Vorsicht behandelt werden. Die Temperaturmessungen an den beiden Stellen ermöglichen zusammen mit früher an der RISP-Bohrstelle beobachteten Temperaturen eine Abschätzung der Aktivationsenergie im festen Eis. Die den beobachteten Werten angepassten Modelle deuten darauf hin, dass die "effektive" Aktivationsenergie im festen Eis wesentlich näher bei $0,15 \mathrm{eV}$ $\left(14 \mathrm{~kJ} \mathrm{~mol}^{-1}\right)$ als bei $0,25 \mathrm{eV}\left(24 \mathrm{~kJ} \mathrm{~mol}^{-1}\right)$ liegt. Es wird angenommen, dass diese Differenz durch die Abnahme des Gehalts an Ionen-Verunreinigungen mit zunehmender Eistiefe um einen Faktor von zwei oder mehr verursacht wird.

\section{INTRODUGTION}

As part of the Ross Ice Shelf Geophysical and Glaciological Survey (RIGGS), I7 d.c. electrical resistivity profiles have been completed at i I locations on the Ross Ice Shelf. During the first RIGGS season (1973-74) electrical resistivity measurements were made at the RIGGS base camp (station B.C.) (Bentley, r 977). A computer program was developed to calculate apparent resistivities on an ice shelf in which the density and temperature, and thus the resistivity, vary continuously with depth. Also, studies of the mass balance at the ice-water boundary beneath the ice shelf, upon which the englacial temperatures depend, were carried out. However, since neither the actual temperatures nor the activation energy were

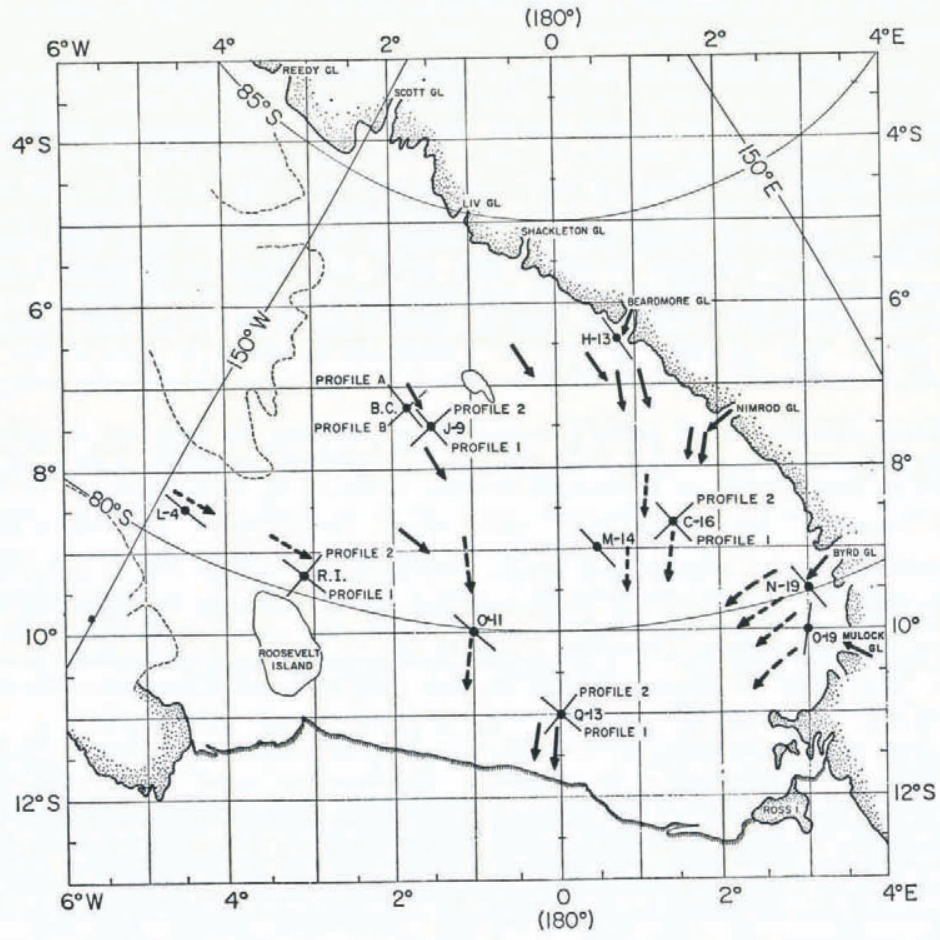

Fig. I. Map of the Ross Ice Shelf, showing the locations and orientations of the resistivity profiles (- - - Solid arrows indicate measured flow directions (Swithinbank, 1963; Dorrer and others, 1969; Thomas, 1976). Dashed arrows show inferred flow directions (Robin, 1975; Bentley and others, 1979). Grid North is towards the top of the figure. 
accurately known, the bottom balance-rate $\dot{b}_{H}$ was difficult to evaluate. Measurements at station R.I. in 1974-75 yielded no new information on bottom balance-rates because of the discovery of highly resistive ice at the base of the shelf (Bentley, 1976). During the 1976-77 field season, drilling was completed down to a depth of $320 \mathrm{~m}$ at the RISP drill site (J-9) on the Ross Ice Shelf, about $30 \mathrm{~km}$ down-stream from station B.C. Temperature-depth measurements then became available for further investigations of the dependence of resistivity on temperature (Bentley, I979).

In $1976-77$ and $1977-78$, resistivity sounding was extended to eight other stations (Fig. I). Density-depth information was obtained from seismic short-refraction shooting, and radar soundings yielded the ice thicknesses along the resistivity profiles. The measurements reported on here cover five of these stations (C-I6, M-I4, O-I I, O-I9, and Q-I3), where the form of the apparent resistivity curves was relatively simple. Temperature-depth data were collected from $100 \mathrm{~m}$ drill holes at the two RIGGS base camps (C-16 and Q-13) and have kindly been made available to the authors in advance of publication (personal communications from C. C. Langway, Jr, and E. Chiang, 1978, and J. H. Cragin, I977).

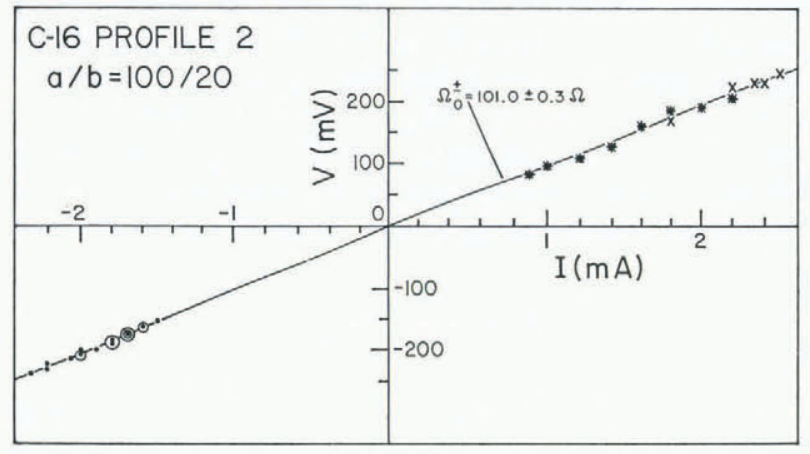

(a)

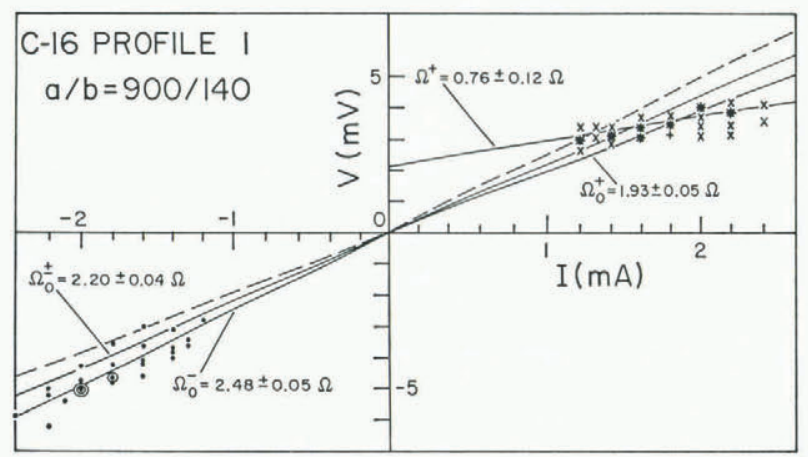

(b)

Fig. 2. Sample plots of observed potential difference V versus current I at $C-I 6 . \times$ and $*$ ( first quadrant) denote current flow in the "positive" direction; $\times$ indicates one reading and * two or more readings plotted at the same point on the graph. Dots (single readings) and circles (multiple readings) denote current flow in the negative direction (plotted in the third quadrant $)$. Superscripts,,+- and \pm on the symbol $\Omega$ denote slopes determined from first-quadrant data only, thirdquadrant data only, and the average of the two $\left(\Omega_{0}^{ \pm}=\frac{1}{2}\left(\Omega_{0}{ }^{+}+\Omega_{0}{ }^{-}\right)\right)$, respectively. The subscript o indicates that the regression line was forced through the origin. The solid lines indicate regression lines with slopes as shown. The dashed lines are the extension of the $\Omega_{0}^{-}$and the $\Omega_{0}+$ lines into the first and third quadrants, respectively. $a$ (upper) is for $a=100 \mathrm{~m}, b=20 \mathrm{~m} ; b$ (lower) is for $a=900 \mathrm{~m}, b=140 \mathrm{~m}$. 


\section{Field METHOD AND RESUlts}

The Schlumberger array configuration (Bentley, 1977) was used throughout the investigation. The current-electrode separation was increased to at least $500 \mathrm{~m}$ at all stations, and as far as $1000 \mathrm{~m}$ at station C-I6. Two perpendicular profiles were completed at C-I6 and at Q-13, one each at the other sites.

The current $I$ was provided by dry-cell batteries supplying voltages up to $2.8 \mathrm{kV}$, and was measured with a Triplett d.c. ammeter. The potential difference $V$ was measured with a battery-operated electrometer (Keithley Instruments, model 6ooA or 6ooB), having an input impedance greater than ${ }^{1} \mathrm{O}^{14} \Omega$. Sections of copper pipe were used for electrodes. To reduce the contact resistance between the firn and the current electrodes salt solution was poured around the electrodes, multiple electrodes were used for the larger current-electrode spacings.

\section{DAta ANALYSis}

A data set for a particular electrode spacing usually consisted of four to eight series of readings of the decay of $V$ and $I$. The direction of current flow was reversed between consecutive series to counteract the polarization effect at the current electrodes. Background potentials were largely balanced by circuitry in the electrometer, and their effect was further reduced by correcting for open-circuit readings before and after each $V-I$ series. Data were analyzed by plotting $V$ versus $I$ for each configuration of electrodes (see examples in Fig. 2a; see also Bentley, $\mathbf{1 9 7 7}$, fig. 3). A straight line, forced through the origin, was fitted by leastsquare analysis to each set of data, the slope giving the resistance $\Omega$ of the ice for that particular configuration. The apparent resistivity $\rho_{\mathrm{a}}$ is then given by $\rho_{\mathrm{a}}=\kappa \Omega$, where

$$
\kappa=\frac{\pi a^{2}}{2 b}\left(\mathrm{I}-\frac{b^{2}}{a^{2}}\right),
$$

$a$ and $b$ are current and potential electrode separations from the center respectively (see Bentley, 1977).

If there was more than one point at the same current-electrode spacing, the weighted average apparent resistivity $\bar{\rho}_{\mathrm{a}}$ was calculated from the equation

$$
\bar{\rho}_{\mathrm{a}}=\frac{\sum_{i=1}^{m} \frac{\left(\rho_{\mathrm{a}}\right)_{i}}{\left(\sigma_{\rho}\right) i^{2}}}{\sum_{i=1}^{m} \frac{\mathrm{I}}{\left(\sigma_{\rho}\right) i^{2}}}
$$

the corresponding standard error estimate $\bar{\sigma}_{\rho}$ being given by

$$
\bar{\sigma}_{\rho}^{2}=\frac{\mathrm{I}}{\sum_{i=1}^{m} \frac{\mathrm{I}}{\left(\sigma_{\rho}\right) i^{2}}}+\frac{\mathrm{I}}{m}\left[\frac{\sum_{i=1}^{m} \frac{\left(\rho_{\mathrm{a}}\right) i^{2}}{\left(\sigma_{\rho}\right) i^{2}}}{\sum_{i=1}^{m} \frac{\mathrm{I}}{\left(\sigma_{\rho}\right) i^{2}}}-\left(\bar{\rho}_{\mathrm{a}}\right)^{2}\right],
$$

where $\left(\rho_{\mathrm{a}}\right)_{i}$ and $\left(\sigma_{\rho}\right)_{i}$ are individual apparent resistivities and standard errors, respectively. 


\section{General features of the Resistivity SOUNDing Gurves}

The resistivity curves on the ice shelf may be divided into two main groups which differ at large electrode separations. At separations less than one or two hundred meters most of the curves are similar, showing three characteristic zones (Fig. 3). For $a<$ ro $\mathrm{m}$, all the curves reflect the near-surface layer of seasonal temperature changes and local inhomogeneities. The second zone, from so to $100 \mathrm{~m}$, reflects primarily the increasing density with depth in the upper $50 \mathrm{~m}$ of the ice shelf. The third zone, from $100 \mathrm{~m}$ to a distance which is, for most profiles, roughly equal to the ice thickness, is affected principally by the temperature gradient and the activation energy in the solid ice. At greater distances the two groups of curves diverge, "Type I" (M-I4, O-I9, unlabelled curves) showing apparent resistivities that decrease rapidly with distance, owing to the high conduction in the sea-water beneath the ice shelf, and "Type 2" (R.I., H-I 3, L-4, N-I9) showing instead an increasing apparent resistivity revealing a zone of highly resistive ice, presumably at the base of the ice shelf, in which the resistivity is substantially higher than in the ice above. Type 2 profiles are associated either with major ice streams from West Antarctica (L-4, R.I.) or large outlet glaciers from East Antarctica (H-I $3, \mathrm{~N}-\mathrm{I} 9$ ). In this paper we consider only Type I curves since they more clearly reflect englacial temperatures.

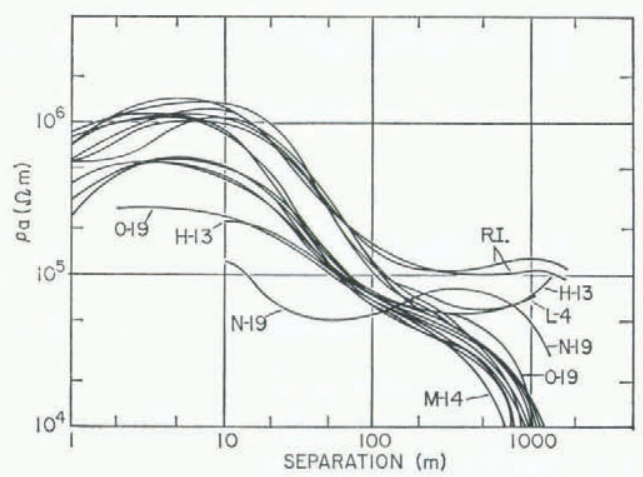

Fig. 3. Electrical resistivity sounding curves obtained on the Ross Ice Shelf. Some of the curves are identified by station of

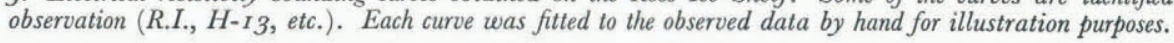

\section{Analysis}

Model resistivities were calculated using the computer program developed by Bentley (1977). The resistivity $\rho$ was assumed to vary with temperature $T$ according to an Arrhenius law with activation energy $E$ :

$$
\rho \propto \exp (E / k T)
$$

where $k$ is Boltzmann's constant $\left(8.62 \times 10^{-5} \mathrm{eV} \mathrm{K}^{-1}=1.3^{8} \times \mathrm{IO}^{-23} \mathrm{~kJ} \mathrm{~mol}^{-1} \mathrm{~K}^{-1}\right)$. Temperatures were calculated from the steady-state model of Crary (196r):

$$
\frac{T-T_{0}}{T_{H}-T_{0}}=\frac{\int_{0}^{z} \exp \left\{\frac{1}{\alpha}\left[\dot{b}_{0} z-\frac{z^{2}}{2 H}\left(\dot{b}_{0}+\dot{b}_{H}\right)\right]\right\} \mathrm{d} z}{\int_{0}^{H} \exp \left\{\frac{1}{\alpha}\left[\dot{b}_{0} z-\frac{Z^{2}}{2 H}\left(\dot{b}_{0}+\dot{b}_{H}\right)\right]\right\} \mathrm{d} z},
$$


where $T_{0}$ is the surface temperature, $T_{H}$ the basal temperature $\left(-2^{\circ} \mathrm{C}\right), \alpha$ the thermal diffusitivity (taken to be $\mathrm{I} .2 \times 1 \mathrm{I}^{-6} \mathrm{~m}^{2} \mathrm{~s}^{-1}$ ), $\hat{b}_{0}$ the surface balance rate, $\hat{b}_{H}$ the basal balancerate, and $H$ the ice thickness. It is important to note that the use of a steady-state model implies that quantitative estimates of $\hat{b}_{H}$ refer to average values over a time interval comparable to the response time of the ice shelf to temperature changes at its base, that is, several hundred years.

Firn densities for each station were determined from seismic refraction shooting along the same lines as the resistivity profiles (Kirchner, unpublished). For the influence of density upon resistivity, Looyenga's equation (Looyenga, 1965) was used, leading to the relation

$$
\rho_{\mathrm{f}}=\rho_{\mathrm{i}} / v^{3},
$$

where $\rho_{\mathrm{f}}$ and $\rho_{\mathrm{i}}$ are the resistivities of firn and ice, respectively, and $v$ is the firn-ice density ratio (see Bentley, $\mathbf{1 9 7 7}$, for a detailed discussion). The ice thickness $H$ at each station was determined by radar sounding along each resistivity profile (authors' unpublished data). Values for $\dot{b}_{0}$ and $T_{0}$ were taken either from Clausen and Dansgaard (1977) or from pit studies during I.G.Y. traverses (Crary and others, I962).

We have tried two simple models of the activation energy based on our previous field work (Bentley, I977, I979) and laboratory measurements by several others (see summary in Glen and Paren, 1975)

$$
E_{2}= \begin{cases}\mathrm{r} \mathrm{eV}\left(96 \mathrm{~kJ} \mathrm{~mol}^{-\mathrm{I}}\right), & z<40 \mathrm{~m}, \\ 0.25 \mathrm{eV}\left(24 \mathrm{~kJ} \mathrm{~mol}^{-1}\right), & z>40 \mathrm{~m}\end{cases}
$$

and

$$
E_{3}= \begin{cases}\mathrm{I} \mathrm{eV}\left(96 \mathrm{~kJ} \mathrm{~mol}^{-1}\right), & z<40 \mathrm{~m}, \\ 0.15 \mathrm{eV}\left(14 \mathrm{~kJ} \mathrm{~mol}^{-1}\right), & z>40 \mathrm{~m} .\end{cases}
$$

These two models were applied previously to observations at station B.C. and J-9 (RISP Drill Camp), the fit appearing somewhat better for $E=0.15 \mathrm{eV}$ than for $E=0.25 \mathrm{eV}$ (Bentley, 1979). This is also true for almost all cases in this paper.

Recent chemical analysis on the ice-core samples from the RISP drill site (Herron and Langway, 1979) showed an exponential decrease in sodium-ion concentration as a function of depth, from roo p.p.b. (parts per billion) at the surface to about 65 p.p.b. at a depth of $50 \mathrm{~m}$, and to about 30 p.p.b. at $130 \mathrm{~m}$. Similar results have been reported for the Little America V core by Langway and others (1974), except that the value obtained there for the surface concentration was about 480 p.p.b. Decrease in chemical content with distance from the ice front for sites on the Ross Ice Shelf have been reported by Warburton and Linkletter (1977) and Herron and Langway (1979). The latter report an observed six-fold decrease in average sodium concentration in surface snows from 600 p.p.b. at the ice front to roo p.p.b. at the RISP drill site, $450 \mathrm{~km}$ from the ice front.

Gross and others (1978) reported that, in solid ice, the resistivity is proportional to $C^{-0.4}$, where $C$ is the impurity concentration. These considerations led Bentley (1979) to conclude that an activation energy of $0.15 \mathrm{eV}\left(14 \mathrm{~kJ} \mathrm{~mol}^{-1}\right.$ ) is probably only apparent and that the results at J-9 are consistent with a true value of $0.25 \mathrm{eV}\left(24 \mathrm{~kJ} \mathrm{~mol}^{-1}\right)$ for the activation energy. If that is correct, then apparent activation energies around $0.15 \mathrm{eV}\left(14 \mathrm{~kJ} \mathrm{~mol}^{-1}\right)$ elsewhere on the ice shelf probably have a similar explanation.

Other factors, such as total gas content, ageing, grain size, and crystalline structure could conceivably cause variation of resistivity with depth. They have not been included in the current analysis because their effects are largely unknown (see Bentley, 1979). 
In order to obtain estimates of the bottom balance-rate $b_{H}$ for each station, we have treated $E$ and $\dot{b}_{H}$ as parameters in the model curves. These model curves were matched to the observations at $200 \mathrm{~m}$ (sometimes $100 \mathrm{~m}$ ) since we are concerned with effects in the solid ice at depths greater than $100 \mathrm{~m}$, and wish to avoid any consideration of fit in the densitydominated region of the $\rho_{\mathrm{a}}$ curves. The parameters of the best model fits are shown in Table I.

TABle I. Summary of RIGGS Resistivity stations, and Parameters used to Galculate the BEST MODEL FIT TO THE DATA FOR EACH STATION

\begin{tabular}{|c|c|c|c|c|c|c|}
\hline Station & $\begin{array}{l}\text { Position } \\
\text { grid }\end{array}$ & $\begin{array}{c}\text { Surface } \\
\text { temperature } \\
{ }^{\circ} \mathrm{C}\end{array}$ & $\begin{array}{l}\text { Surface } \\
\text { balance } \\
\text { rate } \\
\mathrm{m} \text { year }^{-\mathbf{r}}\end{array}$ & $\begin{array}{l}\text { Activation } \\
\text { energy in } \\
\text { solid ice } \\
\mathrm{eV}\end{array}$ & $\begin{array}{c}\text { Basal } \\
\text { balance } \\
\text { rate } \\
\mathrm{m}^{\text {year }}{ }^{-1}\end{array}$ & $\begin{array}{c}\text { Ice } \\
\text { thickness } \\
\mathrm{m}\end{array}$ \\
\hline Q-13 & I $1.04^{\circ} \mathrm{S} ., 0.01^{\circ} \mathrm{W}$. & -27.0 & 0.18 & 0.15 & 0 & 335 \\
\hline O-I & 10 ${ }^{\circ}$ S., $1^{\circ} \mathrm{W}$ & -27.5 & 0.12 & 0.15 & o & $\begin{array}{l}30 J \\
390\end{array}$ \\
\hline M-14 & $8.99^{\circ}$ S., $0.49^{\circ}$ E. & -27.0 & 0.13 & $0.25 \dagger$ & o & 349 \\
\hline C-16 & $8.69^{\circ}$ S., $1.45^{\circ}$ E. & -26.8 & 0.16 & 0.15 & o & 378 \\
\hline O-r 9 & $10.03^{\circ} \mathrm{S} ., 3.00^{\circ} \mathrm{E}$. & -25.0 & $0.2 \mathrm{I}$ & 0.15 & $-0.5 \dagger$ & 472 \\
\hline B.C. * & $7.24^{\circ}$ S., $1.8^{\circ} \mathrm{W}$. & -27.2 & 0.08 & 0.15 & o & 493 \\
\hline $\mathrm{J}_{-0}$ & $7.4^{\circ}$ S., $1.5^{\circ} \mathrm{W}$. & -27.2 & 0.12 & 0.15 & o & 420 \\
\hline
\end{tabular}

* Bentley (1977, 1979).

$\uparrow$ See discussion in the text, p. $34^{1}$.

\section{Station Q-I3}

The apparent resistivities measured on the two profiles are different for separations greater than roo m (Fig. 4). Several models were tried; the two that matched "Profile I" best are shown in the Figure. No model was found that matched "Profile 2" although the quality of the data for "Profile 2" is high (there are as many as five measurements, using different source voltages and potential-electrode separations, at some distances). The anisotropy is probably real and may be related to the buried rift zones known to occur within $3 \mathrm{~km}$ of Q-13 (authors' unpublished radar profiling data).

Measured temperatures in the ice (personal communication from J. H. Cragin, 1977) are in good agreement with the calculated model $E=E_{3}, b_{H}=0$ (Fig. 5). Since this model also fits Profile I, we prefer it for station Q-13.

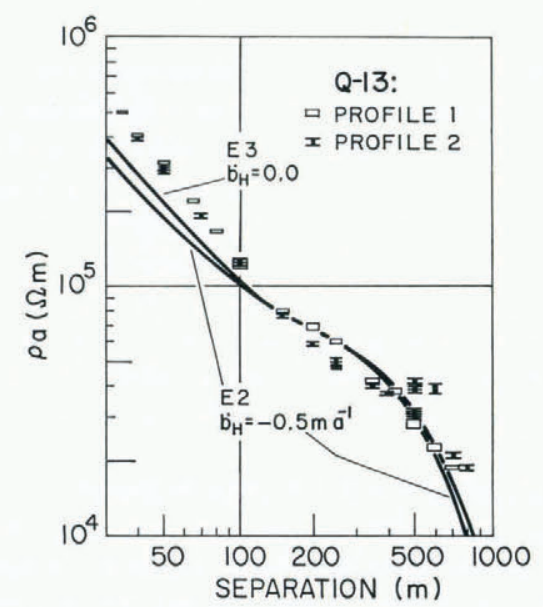

Fig. 4. Plot of apparent resistivities for both profiles at station Q-I3. The height of each symbol represents the standard deviation calculated from linear fits to plots like those in Figure 2. The solid curves are the calculated models described in the text, with $E$ and $b_{H}$ as shown. 


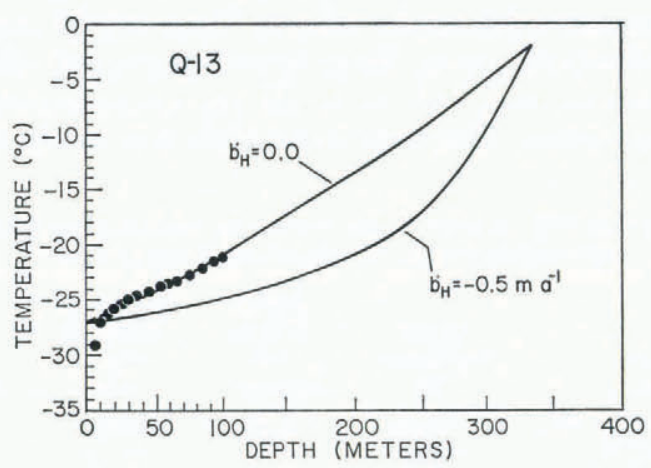

Fig. 5. Calculated temperature-depth curves for station Q-I3 corresponding to models shown in Figure 4. Solid dots indicate temperatures measured in the $100 \mathrm{~m}$ core hole at $Q-I_{3}$.

\section{Station $O-I I$}

Several models with different set of parameters were tried; two, $E=E_{3}, \dot{b}_{H}=0$ and $E=E_{2}, \dot{b}_{H}=-0.5 \mathrm{~m}$ year $^{-1}$ (i.e. $0.5 \mathrm{~m}$ year $^{-1}$ melting), are shown with the measured apparent resistivities (Fig. 6). The former appears to fit somewhat better than the latter.

\section{Station $M-14$}

Of the three model curves shown (Fig. 7), the one with $E=E_{2}, b_{H}=0$ fits the observed values best. Note the small effect of a bottom freeze-rate as large as $0.4 \mathrm{~m}_{\text {year }}{ }^{-1}$, showing the poor sensitivity to positive values of $\dot{b}_{H}$ at stations where the ice is relatively thin and the relatively flat "third zone" of the apparent resistivity curve is short in length. A bottom freeze-rate of $\mathrm{I} \mathrm{m}_{\mathrm{mear}}{ }^{-1}$ or so would be needed to yield a fit with $E=E_{3}$. Note, however, that Crary's ( I96r) temperature model can no longer be applied quantitatively to resistivities when bottom freezing occurs because of the greatly reduced resistivity of saline ice (see the Discussion section below).

\section{Station $C-16$}

The resistivity soundings made along two perpendicular profiles were nearly in agreement and were combined after the removal of an i $1 \%$ average difference. The combined profile is shown in Figure 8, along with two model curves with the same activation energy $E_{3}$, one with $\dot{b}_{H}=-0.5 \mathrm{~m}$ year-1 and the other with $\dot{b}_{H}=0$. The latter model fits the observed values up to a separation of $300 \mathrm{~m}$, but at greater distances the observed values of apparent resistivity are significantly high, so that no simple model fits.

Measured temperatures (personal communication from C. C. Langway, Jr, and E. Chiang, I 978) and the two temperature models are shown in Figure 9; clearly, the model with $\dot{b}_{H}=0$ is in excellent agreement with the measured values (the slight displacement reflects an improper choice of $T_{0}$ in the model calculation which was carried out before the observations were available).

It is tempting to conclude that there is a highly resistive basal layer at the bottom of the ice shelf similar to, but thinner than, the one that presumably produced the "Type 2" curve at the mouth of Beardmore Glacier (station H-13), since C-I6 lies on Beardmore Glacier ice directly down-stream (Bentley and others, 1979). However, it is first necessary to examine the data collected at this station more carefully. At separations of $400 \mathrm{~m}$ and larger the points on the $V-I$ plots deviate increasingly from well-defined straight lines (the worst case is shown in 


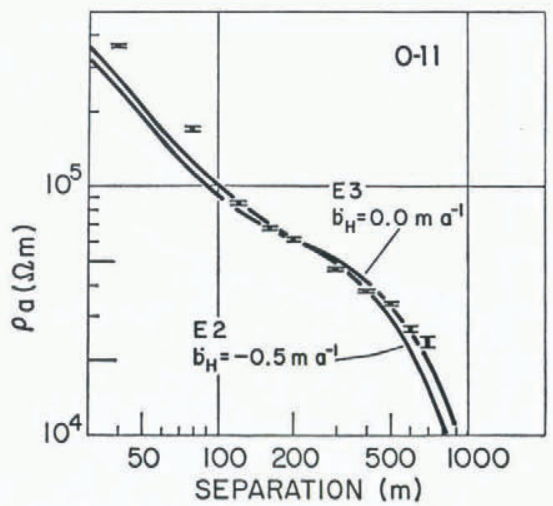

Fig. 6. Plot of apparent resistivity at station $0-11$. Solid curves are calculated models with parameters as shown.

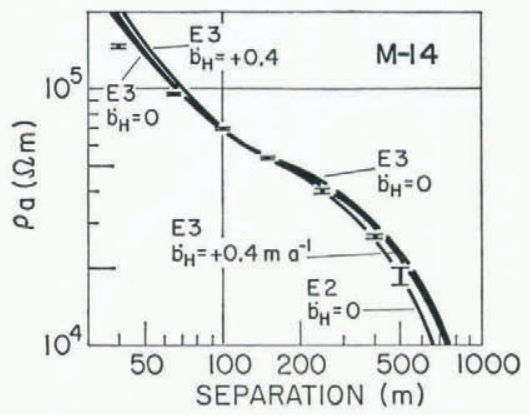

Fig. 7. Plot of apparent resistivity at station M-I4. Solid curves are calculated models with parameters as shown.

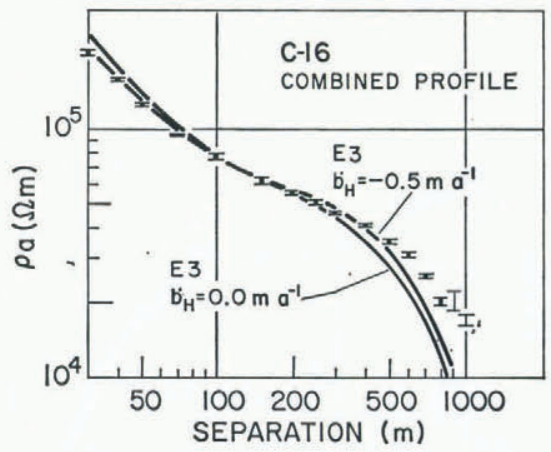

Fig. 8. Apparent resistivity data from station $C-16$. Apparent resistivities for each profile were obtained using the $\Omega_{0}^{ \pm}$values (see Fig. 2), and then combined as discussed in the text. Solid curves are calculated models with parameters as shown. The $\rho_{\mathrm{a}}$ points shown with light bars at separations of $900 \mathrm{~m}$ and $\mathrm{I}$ ooo $\mathrm{m}$ come from only one of the two profiles at $C-I 6$. 


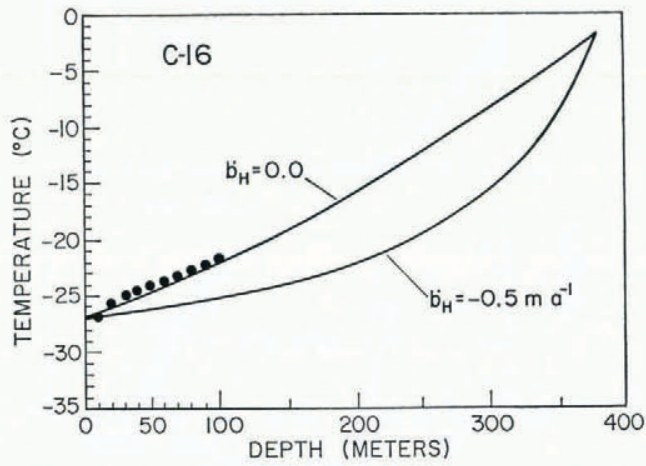

Fig. 9. Calculated temperature-depth curves for station $C-16$ corresponding to models shown in Figure 8 . Solid dots indicate temperatures measured in the $100 \mathrm{~m}$ core hole at $\mathrm{C}-\mathrm{I} 6$.

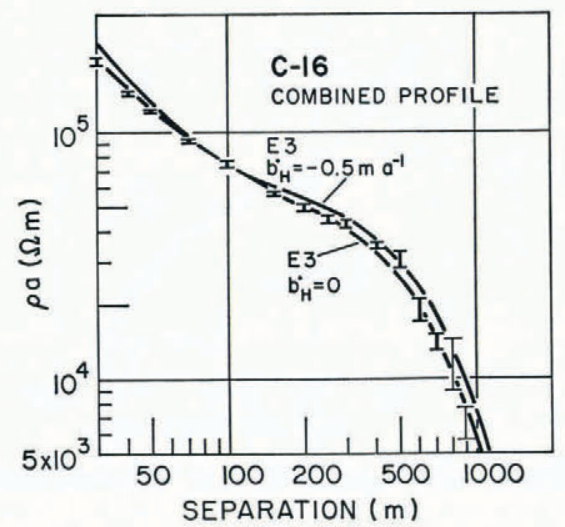

Fig. Io. Apparent resistivity data from station $C-16$. This figure is the same as Figure 8 except that apparent resistivities for each profile were obtained using the $\Omega^{+}$values (see Fig. 2). The $\rho_{\mathrm{a}}$ points shown with light bars at separations of $800 \mathrm{~m}$ and $900 \mathrm{~m}$ come from only one of the two profiles at $C-16$.

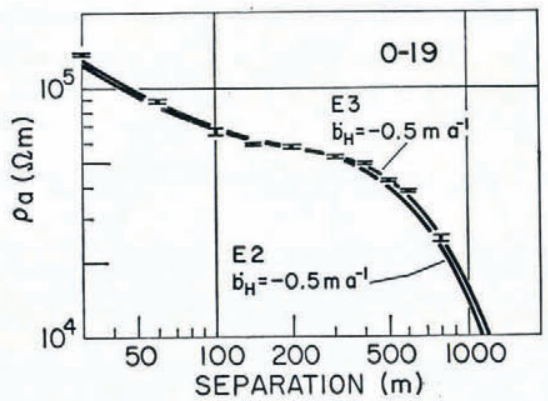

Fig. II. Plot of apparent resistivity at station O-I9. Solid curves are calculated models with parameters cs shown. 
Fig. 2b; see also the well-defined line in Fig. 2a). The best-straight-line fit to the first-quadrant data deviates markedly from its constrained passage through the origin. The cause of this non-zero intercept is not known. To put the magnitude of the deviation in perspective, firstand third-quadrant data were fitted with separate regression lines that were not forced through origin. Calculating apparent resistivity from the third-quadrant slopes yielded results not much different from Figure 8, but use of the first-quadrant slopes cause a large decrease in the observed values (Fig. 2b), enough to bring them into agreement with the model curves (Fig. 10). Although we know of no valid experimental reason for accepting the first-quadrant slopes rather than those drawn through the origin, the results are striking enough to make any conclusion about a basal layer in the ice premature.

\section{Station $O-19$}

Two models are presented for this resistivity sounding, both with $b_{H}=-0.5 \mathrm{~m}$ year ${ }^{-1}$, but with different activation energy functions (Fig. I I). The model with $E=E_{3}$ and $\hat{b}_{H}=-0.5 \mathrm{~m}$ year $^{-1}$ fits the data better. A third model with $\dot{b}_{H}=0$ and $E=E_{3}$ (not shown in Fig. II) did not fit the data at all well.

Station O-I9 is about $310 \mathrm{~km}$ from the ice front, but only $75 \mathrm{~km}$ from Mulock Glacier, which is the source of the ice at this site, as shown by the strong radar reflections (Bentley and others, I979). The ice at this location has thus only a relatively short residence time of perhaps 250 years on the ice shelf (using the discharge velocity of $290 \mathrm{~m}^{-1} \mathrm{er}^{-1}$ measured for Mulock Glacier (Swithinbank, I963)), compared with a transient temperature decay constant of some 700 years (calculated from appendix A, equation (2), in Wexler (1960)), so that the assumption of steady-state conditions at O-I9 (and at other locations close to outlet glaciers) is probably invalid. Alternatively, because of the proximity of this station to Mulock Glacier, there may be a thin, highly-resistive, basal ice layer similar to that suggested as a possibility at station C-I6. In either case, the indicated bottom melt-rate of $0.5 \mathrm{~m}$ year ${ }^{-1}$ could be seriously in error and, in fact, not reflect true melting at all.

\section{Discussion}

The resistivity profiles presented here lie in the grid eastern half of the Ross Ice Shelf, at distances between 90 and $400 \mathrm{~km}$ from the ice front. At only one, O-r 9 , is there any suggestion of bottom melting, but the lower temperatures that are indicated by the resistivities there more likely occur because the ice has recently been discharged from Mulock Glacier than because of an equilibrium melt condition. Unfortunately, the profiles at Q-I3, closest to (about $90 \mathrm{~km}$ from) the ice front, are disturbed by local inhomogeneities, nevertheless, the best model fitted to the data, as well as the temperature measurements to a depth of $100 \mathrm{~m}$, suggests no bottom melting. With an ice movement-rate here of the order of $\mathrm{I} \mathrm{km} \mathrm{year-1}$ (Dorrer and others, I969), that would mean no measurable average melting over a few hundred kilometers up-stream from Q-13. This is consistent with the estimate of Zumberge ( 1964 ), based on strain measurements, that the melt-rate decreases from about $\mathrm{I} \mathrm{m}_{\text {year }}{ }^{-1}$ near the ice front to zero at a distance of $80 \mathrm{~km}$ from the margin.

Some of the models of Giovinetto and Zumberge (1968) include bottom freezing-rates of greater than $0.3 \mathrm{~m}_{\text {year }}{ }^{-1}$ at distances of $200 \mathrm{~km}$ or more from the ice front. Large freezingrates are not supported by the temperatures measured directly and deduced from resistivities at stations B.C., J-9, O-I I, and C-I6. Only at M-I4 would a large basal freeze-rate be consistent with the observations.

As pointed out above, however, the simple model of resistivity varying only as a function of temperature in the solid ice breaks down if basal freezing occurs over the several hundred years averaging time implied in $\vec{b}_{H}$, because of the development of a basal zone of relatively 
much more conductive saline ice. A better approximation in this case is simply to reduce the model ice thickness by the thickness of the basal layer. Model fitting on this basis leads to an estimated basal layer thickness of about $30 \mathrm{~m}$.

Detailed radar profiling on the surface of the ice shelf at M-I 4 reveals an irregular, patchy reflector about that distance above the base (Fig. 12). Although it is not clear why a freshsaline ice boundary should be so irregular in geometry and reflectivity, the general agreement between the two lines of evidence suggests such an irregularity strongly.

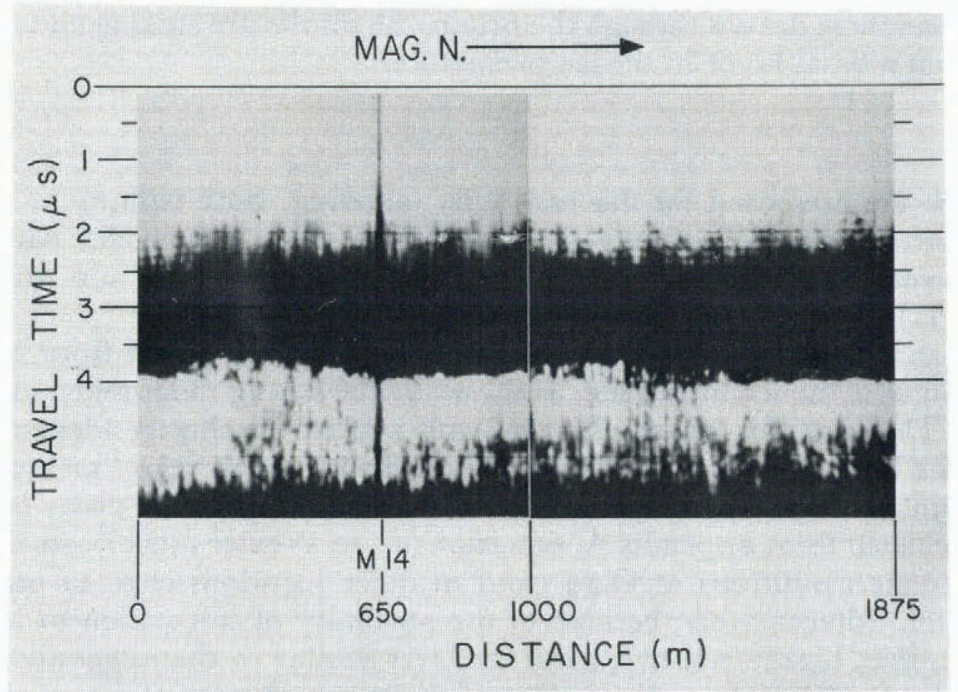

Fig. 12. An intensity-modulated continuous profile carried out at $\mathrm{M-I} 4$ using $35 \mathrm{MHz}$ radar (antenna separation $30 \mathrm{~m}$, attenuation $o d B)$. I $\mu$ s in travel time corresponds to about $85 \mathrm{~m}$ in ice thickness. The scale of distance along the profile is slightly non-linear. The weak, irregular reflection above the ice-water interface suggests possible saline ice at the bottom of the ice shelf.

The assumption of a basal saline layer is greatly strengthened by maps of airborne-radar reflection characteristics which show M-I4 to lie in a poorly-reflecting band (Neal, I979; Bentley and others, I979). Neal (1979) has interpreted this band as arising from basal freezing up-stream of M-I 4, a conclusion supported with additional evidence by Bentley and others (1979). M-I4 is the only resistivity station to lie in one of the poorly-reflecting bands.

Consistent with previous observations at J-9 and B.C. (Bentley, I979), the measurements continue to suggest an "effective" activation energy in the solid ice closer to $0.15 \mathrm{eV}$ (I4 $\left.\mathrm{kJ} \mathrm{mol}^{-1}\right)$ than $0.25 \mathrm{eV}\left(24 \mathrm{~kJ} \mathrm{~mol}^{-1}\right)$.

\section{Acknowledgements}

We are especially grateful to L. L. Greischar for his valuable aid with field work at all the stations. Other individuals whose help in field work or in data reduction made this work possible are: D. G. Albert, H. L. Pollak, and P. R. Risse. The authors are indebted to C. C. Langway, Jr, J. H. Cragin, and E. Chiang for furnishing, in advance of publication, the numerical values of the observed temperatures at stations C-I6 and Q-13.

Field work and data analysis were supported by National Science Foundation grants $\mathrm{OPP}_{72-05805}$ and $\mathrm{DPP}_{76-014}{ }^{15}$. 


\section{REFERENCES}

Bentley, C. R. 1976. High electrical resistivity deep in Antarctic shelf ice of icestream origin. Eos. Transactions, American Geophysical Union, Vol. 57, No. 4, p. 243. [Abstract.]

Bentley, C. R. 1977. Electrical resistivity measurements on the Ross Ice Shelf. Fournal of Glaciology, Vol. 18, No. 78, p. ${ }^{1} 5-35$.

Bentley, C. R. 1979. In-situ measurements of the activation energy for d.c. conduction in polar ice. Fournal of Glaciology, Vol. 22, No. 87, p. 237-46.

Bentley, C. R., and others. 1979. Ice-thickness patterns and the dynamics of the Ross Ice Shelf, Antarctica, by C. R. Bentley, J. W. Clough, K. C. Jezek, and S. Shabtaie. Journal of Glaciology, Vol. 24, No. 90, p. 287-94.

Clausen, H. B., and Dansgaard, W. 1977. Less surface accumulation on the Ross Ice Shelf than hitherto assumed. [Union Géodésique et Géophysique Internationale. Association Internationale des Sciences Hydrologiques. Commission des Neiges et Glaces.] Symposium. Isotopes et impuretés dans les neiges et glaces. Actes du colloque de Grenoble, août/septembre 1975, p. 172-76. (IAHS-AISH Publication No. 118.)

Crary, A. P. I96r. Glaciological studies at Little America Station, Antarctica, 1957 and r958. IGY Glaciological Report Series (New York), No. 5 .

Crary, A. P., and others. 1962. Glaciological regime of the Ross Ice Shelf, by A. P. Crary, E. S. Robinson, H. F. Bennett, and W. W. Boyd, Jr. Journal of Geophysical Research, Vol. 67, No. 7, p. $2791-807$.

Dorrer, E., and others. 1969. Geodetic results of the Ross Ice Shelf Survey expeditions, 1962-63 and 1965-66, by E. Dorrer, W. Hofmann, and W. Seufert. Fournal of Glaciology, Vol. 8, No. 52, p. 67-9o.

Giovinetto, M. B., and Zumberge, J. H. I 968 . The ice regime of the eastern part of the Ross Ice Shelf drainage system. Union de Géodésie et Géophysique Internationale. Association Internationale d'Hydrologie Scientifique. Assemblée générale de Berne, 25 sept.-7 oct. 1967. [Commission de Neiges et Glaces.] Rapports et discussions, p. 255-66. (Publication No. 79 de l'Association Internationale d'Hydrologie Scientifique.)

Glen, J. W., and Paren, J. G. 1975. The electrical properties of snow and ice. Journal of Glaciology, Vol. I5, No. 73 , p. $15-38$.

Gross, G. W., and others. 1978. Electrical conductivity and relaxation in ice crystals with known impurity content, by G. W. Gross, I. C. Hayslip, and R. N. Hoy. Journal of Glaciology, Vol. 2 I, No. 85, p. 143-60.

Herron, M. M., and Langway, C. C., jr. 1979. Dating of Ross Ice Shelf cores by chemical analysis. Fournal of Glaciology, Vol. 24, No. 9o, p. 345-57.

Kirchner, J. F. Unpublished. Seismic refraction studies on the Ross Ice Shelf, Antarctica. [M.S. thesis, University of Wisconsin-Madison, I978.]

Looyenga, H. 1965. Dielectric constants of heterogeneous mixtures. Physica, Deel 31, No. 3, p. $401-06$.

Neal, C. S. 1979. The dynamics of the Ross Ice Shelf revealed by radio echo-sounding. Fournal of Glaciology, Vol. 24, No. 90, p. 295-307.

Robin, G. de Q. I975. Ice shelves and ice flow. Nature, Vol. 253, No. 5488, p. 168-72.

Swithinbank, C. W. M. I 963 . Ice movement of valley glaciers flowing into the Ross Ice Shelf, Antarctica. Science, Vol. I4 I, No. 3580 , p. 523-24.

Thomas, R. H. 1976. Ice velocities on the Ross Ice Shelf. Antarctic Journal of the United States, Vol. I I, No. 4, p. $279-8 \mathrm{r}$.

Warburton, J. A., and Linkletter, G. O. 1977. Precipitation-forming mechanisms and the chemistry of precipitation on the Ross Ice Shelf, Antarctica. [Union Géodésique et Géophysique Internationale. Association Internationale des Sciences Hydrologiques. Commission des Neiges et Glaces.] Symposium. Isotopes et impuretés dans les neiges et glaces. Actes du colloque de Grenoble, aout/septembre 1975, p. 88-94. (IAHS-AISH Publication No. I 18. .)

Wexler, H. I960. Heating and melting of floating ice shelves. Fournal of Glaciology, Vol. 3, No. 27, p. 626-45.

Zumberge, J. H. 1964. Horizontal strain and absolute movement of the Ross Ice Shelf between Ross Island and Roosevelt Island, Antarctica, I958-1963. (In Mellor, M., ed. Antarctic snow and ice studies. Washington, D.C., American Geophysical Union, p. 65-8I. (Antarctic Research Series, Vol. 2.)) 